\title{
Influence of milk urea concentration on fractional urea disappearance rate from milk to blood plasma in dairy cows
}

\author{
J. W. Spek, ${ }^{*} \dagger^{1}$ J. Dijkstra, $\dagger$ and A. Bannink ${ }^{*}$ \\ *Department of Animal Nutrition, Wageningen UR Livestock Research, PO Box 338, 6700 AH Wageningen, the Netherlands \\ †Animal Nutrition Group, Wageningen University, PO Box 338, $6700 \mathrm{AH}$ Wageningen, the Netherlands
}

\begin{abstract}
The relationship between milk urea nitrogen (MUN; $\mathrm{mg}$ of $\mathrm{N} / \mathrm{dL}$ ) and urinary $\mathrm{N}$ excretion is affected, among others, by diurnal dynamics in MUN, which in turn is largely influenced by feed intake pattern and characteristics of urea transfer from blood plasma to milk and vice versa. This study aimed to obtain insight in urea transfer characteristics within the mammary gland and from the mammary gland to blood plasma in dairy cows at various concentrations of plasma urea nitrogen (PUN; mg of N/dL) and MUN. Urea transfer from milk to blood plasma and urea transfer within the mammary gland itself was evaluated in a $4 \times 4$ Latin square design using 4 lactating multiparous HolsteinFriesian cows (milk production of $39.8 \pm 4.70 \mathrm{~kg} / \mathrm{d}$ and $90 \pm 3.9 \mathrm{~d}$ in milk). Treatments consisted of 4 primed continuous intravenous urea infusions of $0,5,10$, and $15 \mathrm{~g}$ of urea/h. Boluses of $\left[{ }^{15} \mathrm{~N}^{15} \mathrm{~N}\right]$ urea were injected in cistern milk at 20,60, and $100 \mathrm{~min}$ before the $1700 \mathrm{~h}$ milking. Milk was collected in portions of approximately $2 \mathrm{~L}$ at the $1700 \mathrm{~h}$ milking. Milk samples were analyzed for urea and enrichment of ${ }^{15} \mathrm{~N}$-urea. Results from one cow were discarded because of leakage of milk from the teats after injection of boluses of $\left[{ }^{15} \mathrm{~N}^{15} \mathrm{~N}\right]$ urea. Increasing urea infusion rate linearly increased PUN from 11.4 $(0 \mathrm{~g}$ of urea $/ \mathrm{h})$ to $25.9 \mathrm{mg} / \mathrm{dL}(15 \mathrm{~g}$ of urea $/ \mathrm{h})$ and MUN from $10.3(0 \mathrm{~g}$ of urea/h) to 23.5 (15 g of urea/h) $\mathrm{mg}$ of $\mathrm{N} / \mathrm{dL}$. The percentage of injected $\left[{ }^{15} \mathrm{~N}^{15} \mathrm{~N}\right]$ urea recovered from milk at the time of injection was not affected by urea infusion rate and varied between 65.1 and $73.0 \%$, indicating that a substantial portion of injected $\left[{ }^{15} \mathrm{~N}^{15} \mathrm{~N}\right]$ urea was not accounted for by collected milk. The estimated fractional disappearance rate of ${ }^{15} \mathrm{~N}$-urea from milk to blood ( $K_{\text {urea }}$; per hour) linearly increased from $0.429(0 \mathrm{~g}$ of urea/h) to 0.641 per hour (15 g of urea/h). Cistern injected $\left[{ }^{15} \mathrm{~N}^{15} \mathrm{~N}\right]$ urea diffused within 20 min after injection toward alveoli milk. Calculations with the average $K_{\text {urea }}$ estimated in this study
\end{abstract}

Received February 4, 2015.

Accepted January 22, 2016

${ }^{1}$ Corresponding author: wouter.spek@wur.nl show that $89 \%$ of an initial difference between PUN and MUN will have disappeared after $4 \mathrm{~h}$. In conclusion, urea disappearance from milk in the mammary gland is substantial, as well as the intramammary urea exchange between cistern, duct, and alveoli milk. However, results have to be interpreted with caution given the lack of full recovery of dosed ${ }^{15} \mathrm{~N}$ urea at time of injection. Information on $K_{\text {urea }}$ is useful to quantify the effects of diurnal variation in PUN on MUN, which enhances the utility of MUN as an indicator for $\mathrm{N}$ excretion in urine.

Key words: dairy cow, urea, urea transfer, milk, blood plasma

\section{INTRODUCTION}

A positive relationship exists between the concentrations of MUN ( $\mathrm{mg}$ of N/dL) and blood plasma (PUN; $\mathrm{mg}$ of $\mathrm{N} / \mathrm{dL}$ ) and the excretion of $\mathrm{N}$ in urine (Ciszuk and Gebregziabher, 1994). Because of this positive relationship, MUN is proposed in several studies as an indicator of urinary $\mathrm{N}$ excretion and ammonia emission (Nousiainen et al., 2004; Burgos et al., 2007; Van Duinkerken et al., 2011b). However, the relationship between MUN and urinary $\mathrm{N}$ excretion is affected by several factors (reviewed by Spek et al., 2013), among others by diurnal dynamics in MUN, which in turn is largely influenced by feed intake pattern (Gustafsson and Palmquist, 1993) and characteristics of urea transfer between blood and milk (Spek et al., 2012a). A substantial number of studies have measured the effect of feed or N intake on diurnal patterns of rumen ammonia (e.g., Gustafsson and Palmquist, 1993; Boucher et al., 2007; Agle et al., 2010) and PUN (e.g., Piccione et al., 2006; Cummins et al., 2009; Røjen et al., 2011). Fewer studies have focused on diurnal variation in PUN and its effect on variation in diurnal MUN. Some studies have measured disappearance of injected labeled urea in the mammary gland of milk goats (Linzell and Peaker, 1971) and of dairy cattle (Spek et al., 2012a). However, these were small-scale studies with a low number of animals, and more information on fractional rates of urea transfer from milk to blood and vice versa are desired 
to predict diurnal variation in MUN based on diurnal variation in PUN. Furthermore, we hypothesized that fractional rates of transfer of urea from the mammary gland to blood and vice versa might be affected by the concentration of MUN or PUN. The aim of this study was to determine urea fractional disappearance rates from the mammary gland and urea transfer characteristics within the mammary gland at various concentrations of PUN and MUN by means of continuous intravenous infusions of urea and by intramammary injected pulse doses of $\left[{ }^{15} \mathrm{~N}^{15} \mathrm{~N}\right]$ urea at various times before milking.

\section{MATERIALS AND METHODS}

The study was approved by the Institutional Animal Care and Use Committee of the Animal Sciences Group, Wageningen University and Research Centre, Lelystad, the Netherlands.

\section{Cows, Housing, and Experimental Design}

Four lactating, multiparous Holstein-Friesian cows were selected based on DIM and milk production. At the start of the experiment, cows had an average BW of $636 \pm 42.7 \mathrm{~kg}$, parity of $2.5 \pm 1.00$, DIM of $90 \pm$ $3.9 \mathrm{~d}$, and milk production of $39.8 \pm 4.70 \mathrm{~kg} / \mathrm{d}$ (values expressed as means $\pm \mathrm{SD}$ ). Cows were housed in a tiestall barn on rubber mats and wood shavings. Cows were randomly assigned to a treatment according to a $4 \times 4$ Latin square design that was orthogonal for carryover effects. Treatments consisted of 4 rates of continuous intravenous urea infusion $(0,5,10$, and 15 $\mathrm{g}$ of urea/h) dissolved in a saline solution administered during sample collection days. The experiment lasted 7 wk and consisted of 3 adaptation weeks to a simultaneous change in housing condition (from free stall to tie stall) and a change from a high protein diet $(\sim 160 \mathrm{~g}$ of $\mathrm{CP} / \mathrm{kg}$ of DM) to the low protein TMR of $135 \mathrm{~g}$ of $\mathrm{CP} / \mathrm{kg}$ of DM (Table 1 ), followed by 4 experimental periods. Each experimental period of 1 wk consisted of 3 sample collection days (Monday, Wednesday, and Friday). The days in between sample collection days were included as washout days for infused urea and injected boluses of labeled urea. Cows had ad libitum access to feed during the first $16 \mathrm{~d}$ of the 3 -wk adaptation period, and subsequently, feed intake was restricted to $95 \%$ of ad libitum feed intake of each individual cow during the rest of the experiment. Cows were milked twice daily at $0500 \mathrm{~h}$ and $1700 \mathrm{~h}$ throughout the experiment. During the noncollection days, cows were fed equal meals twice daily at 0500 and $1700 \mathrm{~h}$, whereas during collection days, $50 \%$ of the daily feed allowance was provided in 6 equal meals every $2 \mathrm{~h}$ from 0500 until
Table 1. Dietary composition ( $\mathrm{g} / \mathrm{kg}$ of DM unless otherwise stated) of the TMR

\begin{tabular}{|c|c|}
\hline Item & TMR \\
\hline \multicolumn{2}{|l|}{ Ingredient } \\
\hline Corn silage ${ }^{1}$ & 668 \\
\hline Wheat straw, chopped & 26 \\
\hline Rapeseed meal & 160 \\
\hline Soybean hulls & 90 \\
\hline Palm fatty acids & 20 \\
\hline Limestone & 10 \\
\hline Sodium carbonate & 10 \\
\hline Molasses & 6.9 \\
\hline Urea & 2.8 \\
\hline Mineral premix ${ }^{2}$ & 2.3 \\
\hline Feed salt ${ }^{3}$ & 1.9 \\
\hline Magnesium sulfate & 1.8 \\
\hline Magnesium oxide & 0.6 \\
\hline \multicolumn{2}{|l|}{ Nutrients } \\
\hline DM (g/kg of feed) & 491 \\
\hline $\mathrm{CP}$ & 135 \\
\hline Ash & 67 \\
\hline Crude fat & 46 \\
\hline Starch & 235 \\
\hline $\mathrm{NDF}$ & 368 \\
\hline $\mathrm{ADF}$ & 236 \\
\hline $\mathrm{Ca}$ & 7.9 \\
\hline $\mathrm{K}$ & 9.6 \\
\hline $\mathrm{Na}$ & 3.8 \\
\hline \multicolumn{2}{|l|}{ Feeding value } \\
\hline $\mathrm{NE}_{\mathrm{L}}^{4}(\mathrm{MJ} / \mathrm{kg}$ of $\mathrm{DM})$ & 6.69 \\
\hline DVE $^{5}$ & 63 \\
\hline $\mathrm{OEB}^{6}$ & 10 \\
\hline Rumen degradable $\mathrm{CP}^{7}$ & 85 \\
\hline
\end{tabular}

${ }^{1}$ Corn silage (g/kg of DM unless specified otherwise): DM, $416 \mathrm{~g} /$ kg; CP, 69; starch, 381; NDF, 353; ADF, 196; ADL, 20; ash, 42 (determined with near infrared spectrometry; Blgg, Wageningen, the Netherlands). Calculated intestinal digestible protein (DVE), $50 \mathrm{~g} /$ $\mathrm{kg}$ of DM; rumen degraded protein balance (OEB), $-41 \mathrm{~g} / \mathrm{kg}$ of DM; $\mathrm{NE}_{\mathrm{L}}, 6.54 \mathrm{MJ} / \mathrm{kg}$ of DM.

${ }^{2}$ Contained per kilogram of mix $108 \mathrm{~g}$ of $\mathrm{Ca} ; 240 \mathrm{~g}$ of $\mathrm{Mg} ; 4,960 \mathrm{mg}$ of $\mathrm{Cu} ; 9,624 \mathrm{mg}$ of Mn; 13,440 mg of Zn; $696 \mathrm{mg}$ of I; $520 \mathrm{mg}$ of Co; 102 $\mathrm{mg}$ of Se; 2,000,000 IU of vitamin A; 440,000 IU of vitamin $\mathrm{D}_{3}$; and $6,000 \mathrm{IU}$ of vitamin E.

${ }^{3}$ Composition of feed salt: $\geq 99.8 \% \mathrm{NaCl}$.

${ }^{4}$ Net energy for lactation calculated with the Dutch VEM (feed unit lactation) system (Van Es, 1975).

${ }^{5}$ Intestinal digestible protein (Van Duinkerken et al., 2011a).

${ }^{6}$ Rumen degraded protein balance (Van Duinkerken et al., 2011a).

${ }^{7}$ Based on the Dutch protein evaluation system (Van Duinkerken et al., 2011a).

$1700 \mathrm{~h}$ to minimize variation in PUN and MUN caused by variation in feed intake during that day. At $1700 \mathrm{~h}$ the remaining $50 \%$ of the total daily feed allowance was provided. Daily individual feed intake in the tie stall was determined by subtracting the fresh weight of orts from the weight of fresh feed supplied.

\section{Infusions and Sample Collection}

Three batches of the TMR were made during the experiment, and each batch was immediately stored at $-20^{\circ} \mathrm{C}$. Two days before feeding, the quantity of feed 
offered per day was taken out of the freezer to defrost, and the average outside temperature (measured at Lelystad airport) during the study period was $6.1^{\circ} \mathrm{C}$. From each TMR batch a representative sample $(\sim 700$ g) was taken immediately after mixing and stored at $-20^{\circ} \mathrm{C}$. During the third week of the experiment, cows were fitted with 3-way blood sampling catheters (BD Careflow triple lumen; Becton Dickinson BV, Breda, the Netherlands) in the jugular vein, and catheters were kept open by a $33 \mathrm{U}$ of heparin/mL saline solution throughout the experiment. The distal and proximal ports of the blood sampling catheters were used for the continuous infusion of urea solutions and the collection of blood samples, respectively, during collection days. During collection days, continuous infusions were given $(37.5 \mathrm{~mL} / \mathrm{h})$ of solutions containing either $0,133,267$, or $400 \mathrm{~g}$ of urea/L of saline via $50-\mathrm{mL}$ syringe pumps (Perfusor Secura FT, B. Braun, Melsungen, Germany), starting at $0600 \mathrm{~h}$ and ending at $1700 \mathrm{~h}$. Just before starting infusions, cows were primed with an intravenous injection of $0,30,60$, and $90 \mathrm{~g}$ of urea (dissolved in saline) for the $0,133,267$, and $400 \mathrm{~g}$ of urea/L infusion treatments, respectively. During collection days a bolus of $\left[{ }^{15} \mathrm{~N}^{15} \mathrm{~N}\right]$ urea was injected in cistern milk at $20 \mathrm{~min}$ before the $1700 \mathrm{~h}$ milking on Monday, 60 min before the $1700 \mathrm{~h}$ milking on Wednesday, and at 100 min before the $1700 \mathrm{~h}$ milking on Friday. The $\left[{ }^{15} \mathrm{~N}^{15} \mathrm{~N}\right]$ urea boluses were injected in the 4 cisterns of the cow via the teat canals by using a crop needle attached to a $10-\mathrm{mL}$ syringe. The teats and crop needle were disinfected before injection of the boluses by spraying with a $70 \%$ ethanol solution before injection to minimize the risk of mastitis. Weights of the boluses injected in the cisterns of the mammary gland for the $0,5,10$, and $15 \mathrm{~g}$ of urea/h infusion treatments were $6.0 \pm 0.13,11.9 \pm 0.08,17.6$ \pm 0.27 , and $23.6 \pm 0.71 \mathrm{mg}$ of $\left[{ }^{15} \mathrm{~N}^{15} \mathrm{~N}\right]$ urea dissolved in saline, respectively. During collection days milk was collected in portions of approximately $2 \mathrm{~L}$ using a WB HI/Pullout Tru-tester device (Tru-Test Ltd., Auckland, New Zealand) at the $1700 \mathrm{~h}$ milking, and each portion was sampled (10 mL per sample). Directly after milking, $20 \mathrm{IU}$ of oxytocin was injected intravenously after which the residual milk was collected and sampled as well (10 $\mathrm{mL}$ per sample). Total milk production during the $1700 \mathrm{~h}$ milking was recorded, and a representative sample of the total collected milk was composed (10 $\mathrm{mL}$ per sample). Blood samples $(10 \mathrm{~mL})$ were taken at $3,2,1$, and $0 \mathrm{~h}$ before the $1700 \mathrm{~h}$ milking and directly put in ice water. The blood samples were centrifuged at $3,000 \times g$ for $15 \mathrm{~min}$ at room temperature, and blood plasma was separated. Blood plasma and milk samples were stored at $-20^{\circ} \mathrm{C}$ pending analysis. During sample collection days (0500-1700 h), water intake for each cow was recorded every $2 \mathrm{~h}$, and total daily drink water intake was recorded from 0500 until $0500 \mathrm{~h}$ the next day.

\section{Analytical Procedures}

Dry matter content of TMR was determined by oven drying at $70^{\circ} \mathrm{C}$ during $24 \mathrm{~h}$. Analysis of $\mathrm{CP}$, NDF, ADF, starch, crude fat, ash, Na, K, and Ca was carried out as described by Spek et al. (2012b). Milk samples taken from the total quantity of milk collected during the $1700 \mathrm{~h}$ milking were analyzed for urea, fat, protein, lactose, and SCC as described by Abrahamse et al. (2008) for all parameters except urea. Milk urea content was determined using the $\mathrm{pH}$ difference technique (ISO 14637; ISO, 2004). Milk samples were defatted and deproteinized by centrifugation at $10,600 \times g$ for 15 min at $4^{\circ} \mathrm{C}$ after precipitation of protein and fat with sulfosalicylic acid (15\%) on a $3: 1$ (vol/vol) milkto-acid ratio. The resulting fat- and protein-free solution was used for analysis of ${ }^{15} \mathrm{~N}$-urea enrichment by EA-IRMS (EA type DP 200 Series 2, IRMS type Delta S; Finnigan, Milan, Italy) according to the procedure described by Spek et al. (2012a). Urea in the fat- and protein-free solution samples of milk was isolated by cation-exchange chromatography (Dowex 50WX8-400 cation-exchange resin, protonated with $0.1 \mathrm{M} \mathrm{HCl} \mathrm{solu-}$ tion; Sigma-Aldrich, Buchs, Switzerland) and elution with water. Prior to analysis of samples, elution profiles were created for the effect of proteins and amino acids on analysis of ${ }^{15} \mathrm{~N}$ urea. Results indicated that errors in analyzed ${ }^{15} \mathrm{~N}$ urea due to unremoved protein or amino acids were small $(<0.5 \%)$. For each cow during each sample collection day, a blood plasma sample was taken at $3 \mathrm{~h}$ before the $1700 \mathrm{~h}$ milking and was analyzed on ${ }^{15} \mathrm{~N}$-urea enrichment in the same manner as analysis of ${ }^{15} \mathrm{~N}$-urea enrichment in milk samples to determine the estimation of background enrichment of ${ }^{15} \mathrm{~N}$-urea in milk. Blood plasma samples at 2, 1 , and $0 \mathrm{~h}$ before the $1700 \mathrm{~h}$ milking were analyzed for urea content. Because of unforeseen circumstances half of the blood plasma samples were analyzed using a method (Urea liquicolor, 12-2003-15, HUMAN, Wiesbaden, Germany) that is based on measuring absorbance of light $(578 \mathrm{~nm})$ after a modified Berthelot reaction, and the other half of the samples were analyzed by using a method (SYNCHRON REF 442750, Beckman Coulter, Etten-Leur, the Netherlands) that measures absorbance of light $(340 \mathrm{~nm})$ after urea is hydrolyzed by means of urease to ammonia and after glutamate dehydrogenase catalyzes the condensation of ammonia and $\alpha$-ketoglutarate to glutamate with the concomitant oxidation of reduced $\beta$-nicotinamide adenine dinucleotide to $\beta$-nicotinamide 
adenine dinucleotide. Both methods used to analyze blood samples on urea were developed for samples including blood plasma.

\section{Statistics}

Effects of urea infusion rate on milk yield, milk composition, water intake, and recovered ${ }^{15} \mathrm{~N}$ urea 20 , 60, and 100 min before milking were analyzed using a mixed linear model (using PROC MIXED of SAS version 9.2; SAS Institute Inc., Cary, NC), with period included as fixed class effect, urea infusion rate as a fixed continuous effect, and cow included as random effect. The fractional disappearance rate of ${ }^{15} \mathrm{~N}$-urea from the milk $\left(\boldsymbol{K}_{\text {urea }}\right)$ was estimated using the NLIN procedure of SAS (version 9.2) and the following model:

$$
\text { Recovered }{ }^{15} \mathrm{~N} \text {-urea (time) }(\%)=A \times e^{-\left(K_{\text {urea }} \times \text { time }\right)} \text {, }
$$

where $A(\%)$ is the estimated (model fitted) fraction of recovered ${ }^{15} \mathrm{~N}$-urea at the time of injection of $\left[{ }^{15} \mathrm{~N}^{15} \mathrm{~N}\right]$ urea in the cisterns of the mammary gland, $K_{\text {urea }}$ (per hour) is the fractional disappearance rate of injected $\left[{ }^{15} \mathrm{~N}^{15} \mathrm{~N}\right]$ urea from the milk, and time $(\mathrm{h})$ is the elapsed time between bolus injection and milking. The $\left[{ }^{15} \mathrm{~N}^{15} \mathrm{~N}\right]$ urea disappearance characteristics $A$ and $K_{\text {urea }}$ were estimated separately for each individual cow for each treatment. Effects of urea infusion rate on the individual estimated $A$ and $K_{\text {urea }}$ were analyzed using the MIXED procedure of SAS and the same mixed linear model described previously. Effects of urea infusion rate on PUN were analyzed using the MIXED procedure of SAS with period and method of analysis included as fixed class effects, urea infusion rate as a fixed continuous effect, and cow included as random effect.

For all mixed models, calculation of error degrees of freedom was done by the DDFM = KENWARDROGER method in PROC MIXED, and the covariance structure was modeled as compound symmetry. Least square estimates were estimated by defining urea infusion rate as a class effect instead of as a continuous effect. Quadratic and cubic effects of urea infusion treatment were tested as well. But, in all cases no significant effects were found, and therefore, these results were not shown. No significant interaction effect $(P=0.264)$ existed between infusion rate and time of $\left[{ }^{15} \mathrm{~N}^{15} \mathrm{~N}\right]$ urea bolus injection before the $1700 \mathrm{~h}$ milking on recovery of injected ${ }^{15} \mathrm{~N}$ labeled urea.

Before statistical analysis observations were averaged per cow per treatment (or per period). Effects of treatments were declared significant at $P \leq 0.05$ and a tendency at $0.05<P<0.10$.

\section{RESULTS}

Cows remained healthy throughout the experiment and no cases of clinical mastitis were observed. From 1 of the 4 cows all results were discarded because of leakage of injected ${ }^{15} \mathrm{~N}$ labeled urea out of the teats resulting in unreliable and unrealistic high fractional disappearance rates of urea from the mammary gland. Dry matter intake; daily water intake; water intake during infusion period; milk production; and concentrations of fat, protein, and lactose in milk did not differ significantly between treatments (Table 2). A tendency $(P=0.098)$ existed for a linear effect of urea infusion rate on SCC, being highest for the lowest urea infusion rate (Table 2). Milk urea concentration and plasma urea concentration increased linearly with increased urea infusion rate (Table 2). Figure 1 illustrates the observed disappearance of ${ }^{15} \mathrm{~N}$-urea in time for the pooled data set of observations. The fitted $K_{\text {urea }}$ estimated on the pooled data set of observations was $0.544 \pm 0.0347$ per hour and is almost identical to the average of all 12 individually estimated $K_{\text {urea }}$ values of $0.547 \pm 0.1212$ per hour. The average $K_{\text {urea }}$ per treatment varied between 0.429 and 0.641 per hour, and a significant positive linear relationship between $K_{\text {urea }}$ and urea infusion rate was observed $(P=0.043$; Table 3$)$. As well, a significant $(P$ $=0.033)$ linear decrease in recovery of injected $\left[{ }^{15} \mathrm{~N}^{15} \mathrm{~N}\right]$ urea at increasing urea infusion levels was observed when boluses of $\left[{ }^{15} \mathrm{~N}^{15} \mathrm{~N}\right]$ urea were injected at $60 \mathrm{~min}$ before milking, but this was not the case when boluses of $\left[{ }^{15} \mathrm{~N}^{15} \mathrm{~N}\right]$ urea were injected at 20 and $100 \mathrm{~min}$ before milking (Table 3). The estimated fraction of injected $\left[{ }^{15} \mathrm{~N}^{15} \mathrm{~N}\right]$ urea recovered from milk at the time of injection was not affected by urea infusion rate and varied between 65.1 and $73.0 \%$ (Table 3) at the lowest and highest urea infusion rate, respectively, suggesting that a substantial portion of injected $\left[{ }^{15} \mathrm{~N}^{15} \mathrm{~N}\right]$ urea was not accounted for by collected milk. In Figure 2, the ${ }^{15} \mathrm{~N}$ urea enrichment in the milk fractions from first milk (cistern) to last (alveoli) milk are plotted for each of the 3 moments before milking (20,60, and $100 \mathrm{~min}$ ) when a bolus of $\left[{ }^{15} \mathrm{~N}^{15} \mathrm{~N}\right]$ urea was injected into the cisterns of the mammary gland. Cistern injected $\left[{ }^{15} \mathrm{~N}^{15} \mathrm{~N}\right]$ urea rapidly diffused within 20 min after injection toward alveoli milk. For the first $50 \%$ of the milk being milked, significant $(P<0.050)$ differences existed in ${ }^{15} \mathrm{~N}$-urea atom percentage excess between all combinations of times of bolus injection moments of 20,60, and 100 min before milking. Furthermore, up until $80 \%$ of the total milk volume being milked, significant $(P \leq 0.015)$ differences existed in ${ }^{15} \mathrm{~N}$-urea atom percentage excess between 20 and 100 min of bolus injection before milking. 
Table 2. Least squares means for DMI, drink water intake, plasma urea concentration, milk production, and milk composition for the various urea infusion rates during sample collection days $(\mathrm{n}=12)$

\begin{tabular}{|c|c|c|c|c|c|c|}
\hline Item & \multicolumn{4}{|c|}{ Urea infusion rate $(\mathrm{g} / \mathrm{h})$} & SEM & $\begin{array}{c}\text { Linear effect } \\
P \text {-value }\end{array}$ \\
\hline Drink water intake daytime ( $\mathrm{kg} / 12$-h sampling period) & 40.6 & 41.1 & 41.9 & 41.5 & 2.20 & 0.353 \\
\hline Plasma urea $\mathrm{N}(\mathrm{mg} / \mathrm{dL})$ & 11.4 & 17.5 & 20.8 & 25.9 & 1.23 & $<0.001$ \\
\hline Milk yield (kg/d) & 31.2 & 31.3 & 31.4 & 31.7 & 2.71 & 0.095 \\
\hline Milk fat $(\%)$ & 4.98 & 4.64 & 4.88 & 4.97 & 0.473 & 0.803 \\
\hline Milk protein (\%) & 3.35 & 3.33 & 3.34 & 3.35 & 0.151 & 0.932 \\
\hline Milk lactose (\%) & 4.65 & 4.62 & 4.66 & 4.66 & 0.082 & 0.449 \\
\hline $\mathrm{SCC}(\times 1,000 / \mathrm{mL})$ & 418 & 190 & 58 & 61 & 156.5 & 0.098 \\
\hline
\end{tabular}

${ }^{1}$ Total water intake for $24 \mathrm{~h}$ from start of sampling at $0500 \mathrm{~h}$ until $0500 \mathrm{~h}$ the next day.

${ }^{2} \mathrm{FPCM}=$ fat- and protein-corrected milk.

\section{DISCUSSION}

\section{Urea Infusion, PUN, MUN, and Water Intake}

Restricted feeding resulted in similar DMI between treatments. A significant effect of urea infusion rate on PUN and MUN was observed, which was expected. Milk yield and contents of fat, protein, and lactose were not affected by urea infusion rate, but SCC tended $(P$ $=0.095)$ to decrease linearly with urea infusion rate. A causal relationship between urea infusion rate and SCC, however, could be excluded because the high $\mathrm{SCC}$ for the $0 \mathrm{~g} / \mathrm{h}$ urea infusion treatment was due to one cow that had high SCC concentrations during the period of receiving the $0 \mathrm{~g} / \mathrm{h}$ urea treatment, whereas SCC concentrations for that cow during the other

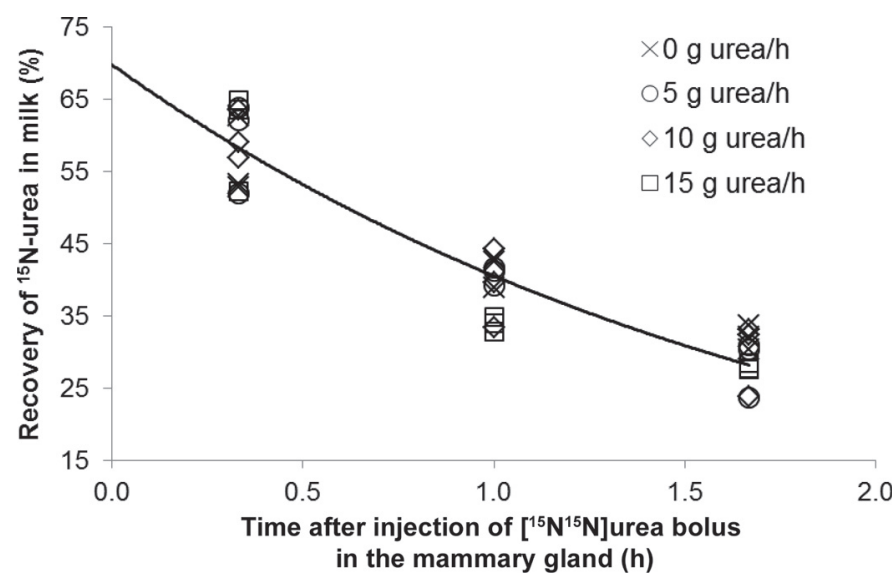

Figure 1. Recovery at milking of $\left[{ }^{15} \mathrm{~N}^{15} \mathrm{~N}\right]$ urea in the mammary gland via the teats at 20,60 , and $100 \mathrm{~min}$ after injection. The estimated parameters for the exponential model based on the pooled data set $(\mathrm{n}=36)$ were $A=69.8 \pm 2.06(\%)$ and $K_{\text {urea }}=0.544 \pm 0.0347$ $\left(/ \mathrm{h} ; \mathrm{R}^{2}=0.89\right)$. treatments were low. Moreover, the other 2 cows did not show increased SCC concentrations during $0 \mathrm{~g} / \mathrm{h}$ urea infusion.

The continuous intravenous infusion of $0,5,10$, and $15 \mathrm{~g}$ of urea/h, respectively, did not affect water intake and is therefore unlikely to have affected urine production.

\section{Urea Disappearance from the Mammary Gland}

In this study a linear increase $(P=0.043)$ in $K_{\text {urea }}$ was found at increasing urea infusion rates, and $K_{\text {urea }}$ varied between 0.429 and 0.641 per hour. Previously, Spek et al. (2012a) reported fractional disappearance rates of urea from the mammary gland of 0.456 and 0.576 per hour in 2 separate pilot trials. The increased $K_{\text {urea }}$ with higher infusion rate in this study is mainly caused by a significantly lower recovery of ${ }^{15} \mathrm{~N}$ urea at 60 min after injection with higher urea infusion rates, rather than at 20 or 100 min after introduction in the udder because at these times urea infusion rate had no significant effect on recovery. Recently, Cui et al. (2014) found mRNA related to urea transmembrane transport and urea transport in mammary gland tissue of 4 lactating Holstein cows to be differentially expressed between cows that were selected for a high milk fat and protein content and cows that were selected for a low milk fat and protein content. The presence of urea transport activity might explain the positive relationship found in this study, although the benefit of regulating urea transport in the mammary gland remains unclear.

Prudence in accepting a positive relationship between $K_{\text {urea }}$ and urea infusion rate is required because previous results from the pilot study by Spek et al. (2012a) indicated a negative effect of MUN on urea clearance from the udder, which is in contrast with the 
Table 3. Least squares means for disappearance characteristics of injected $\left[{ }^{15} \mathrm{~N}^{15} \mathrm{~N}\right]$ urea in the mammary gland for the various urea infusion rates during sample collection days $(\mathrm{n}=12)$

\begin{tabular}{|c|c|c|c|c|c|c|}
\hline \multirow[b]{2}{*}{ Item $^{1}$} & \multicolumn{4}{|c|}{ Urea infusion rate in venous blood $(\mathrm{g} / \mathrm{h})$} & \multirow[b]{2}{*}{ SEM } & \multirow{2}{*}{$\begin{array}{c}\text { Linear effect } \\
P \text {-value }\end{array}$} \\
\hline & 0 & 5 & 10 & 15 & & \\
\hline$A(\%)$ & 65.1 & 70.4 & 72.1 & 73.0 & 5.83 & 0.213 \\
\hline $\begin{array}{l}K_{\text {urea }}(/ \mathrm{h}) \\
{ }^{15} \mathrm{~N} \text {-urea recovered at: }\end{array}$ & 0.429 & 0.561 & 0.556 & 0.641 & 0.0708 & 0.043 \\
\hline $20 \mathrm{~min}$ & 56.8 & 58.3 & 60.4 & 60.0 & 3.71 & 0.352 \\
\hline $60 \mathrm{~min}$ & 40.9 & 40.3 & 39.4 & 34.4 & 1.79 & 0.033 \\
\hline $100 \mathrm{~min}$ & 32.7 & 27.4 & 30.0 & 28.0 & 2.12 & 0.281 \\
\hline
\end{tabular}

${ }^{1} A$ is the model-estimated percentage of recovered ${ }^{15} \mathrm{~N}$-urea at the time of injection of $\left[{ }^{15} \mathrm{~N}^{15} \mathrm{~N}\right]$ urea in the cisterns of the mammary gland. $K_{\text {urea }}$ is the fractional disappearance rate of injected $\left[{ }^{15} \mathrm{~N}^{15} \mathrm{~N}\right]$ urea from the mammary gland, where $A$ is estimated.

positive relationship between $K_{\text {urea }}$ and urea infusion rate (and consequently MUN) observed in the present study. Another reason to carefully evaluate the estimated relationship between $K_{\text {urea }}$ and urea infusion rate is the variable fitted recovery of injected ${ }^{15} \mathrm{~N}$-urea at the time of injection $(A)$. The average of $A$ estimates of $70.1 \pm 8.21 \%$ in the present study was lower than the average $83.5 \%$ established in the pilot study of Spek et al. (2012a). It remains unknown why the fraction of injected $\left[{ }^{15} \mathrm{~N}^{15} \mathrm{~N}\right]$ urea that could not be accounted for is higher than in the previous study of Spek et al. (2012a). Furthermore, results from Table 3 show that at a low urea infusion rate, numerically less ${ }^{15} \mathrm{~N}$-urea was recovered at the time of injection compared with the higher urea infusion rates. Such a result is difficult to explain, and in view of the lack of full recovery of ${ }^{15} \mathrm{~N}$-urea, results have to be interpreted with caution. It is possible that with the ${ }^{15} \mathrm{~N}$ measurements in the milk samples a small fraction of nonurea $\mathrm{N}$ remained in the milk samples, hence diluting the ${ }^{15} \mathrm{~N}$ enrichment analyzed. Because the effect of this dilution will have become smaller with an increase of the urea infusion rate (increasing the milk urea content and hence reducing the effect of the diluting nonurea $\mathrm{N}$ compounds), this also may explain the positive effect of urea infusion rate on fitted values of $K_{\text {urea }}$ ( $49 \%$ increase from lowest to highest infusion rate) and $A$ ( $12 \%$ increase from lowest to highest infusion rate). For this reason we suggest that the values obtained with the highest urea infusion rate are most reliable.

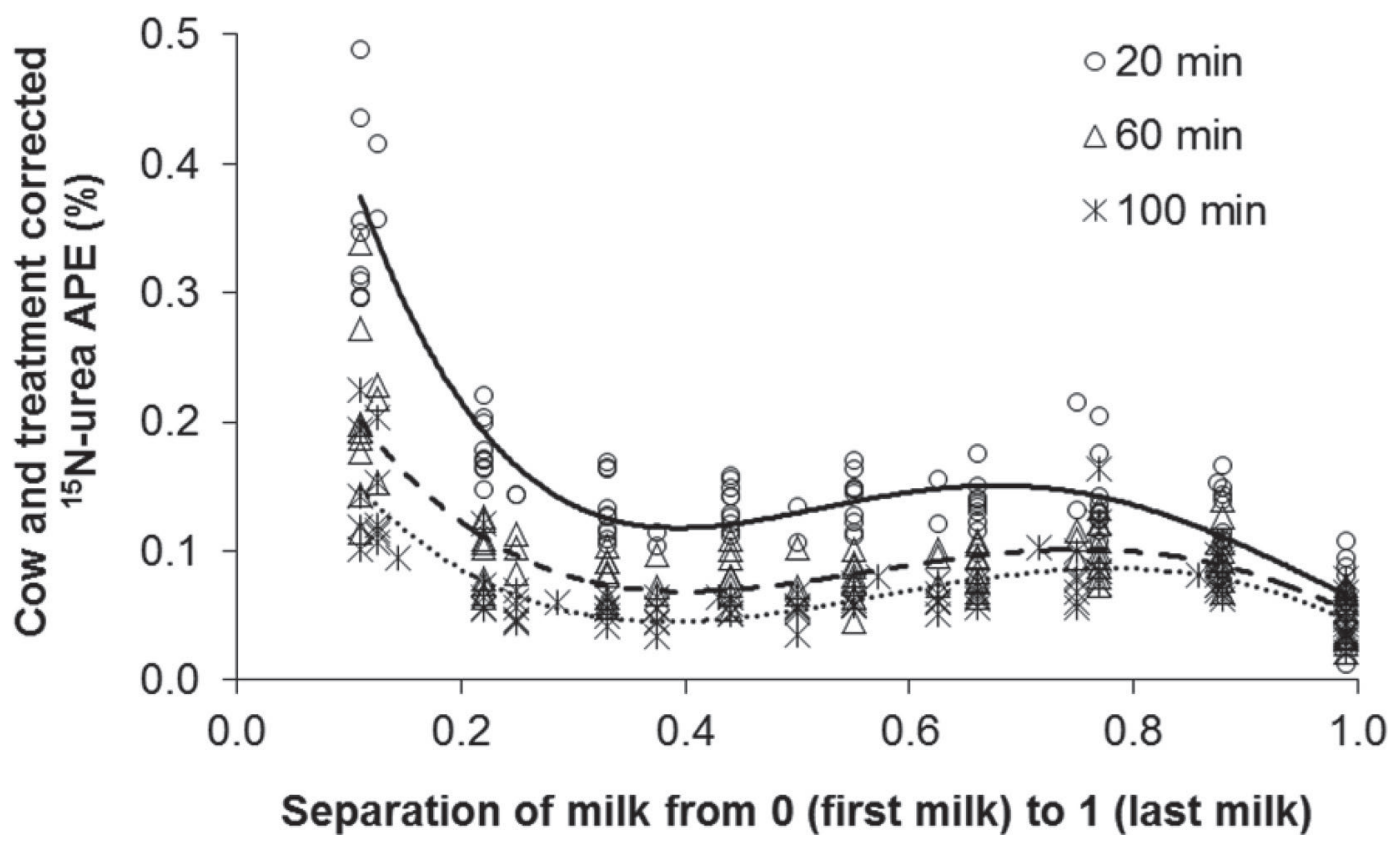

Figure 2. Cow- and treatment-corrected ${ }^{15} \mathrm{~N}$-urea atom percentage excess (APE) in fractions of milk ranging from first milk to last milk after injecting a $\left[{ }^{15} \mathrm{~N}^{15} \mathrm{~N}\right]$ urea bolus in the mammary gland at 20,60, and $100 \mathrm{~min}$ before milking. Fourth order polynomial models were fitted to the data set pooled at 20,60, and $100 \mathrm{~min}$ (solid curve, $20 \mathrm{~min}$; dashed curve, $60 \mathrm{~min}$; dotted curve, $100 \mathrm{~min}$ ). 
Several factors may have contributed to the fraction of injected $\left[{ }^{15} \mathrm{~N}^{15} \mathrm{~N}\right]$ urea apparently unaccounted for immediately after injection $(=100 \%-A)$. One possibility is that the milking process did not remove all the milk within the mammary gland and fluids within the tissues of the mammary gland. Incomplete milk removal was likely not an important factor, because oxytocin was injected intravenously, and as already stated by Knodt and Petersen (1944), oxytocin removes virtually all milk from the alveoli. A second possibility is leakage of milk from the teats after injecting the $\left[{ }^{15} \mathrm{~N}^{15} \mathrm{~N}\right]$ urea until the time of milking. However, this leakage of milk has been carefully monitored during the trial and was minor, except for one cow of which data were not included in the present analysis. A third possibility is hydrolysis of labeled urea into ammonia N (Hommez et al., 1999), and this hypothesis is supported by the numerical linear inverse relationship between SCC and estimated $A$. However, relationships between SCC and measured recovered ${ }^{15} \mathrm{~N}$-urea per time period $(20,60$, and $100 \mathrm{~min}$ ) were not significant and weak. A fourth (previously discussed) possibility is that analyzed ${ }^{15} \mathrm{~N}$ enrichment was not specific for urea because of an incomplete extraction of nonurea $\mathrm{N}$ compounds from the sample. Because this effect must have been very small with the high urea infusion rate (causing milk urea, as most abundant nonprotein $\mathrm{N}$ in milk, to be 2.5 times as high compared with no urea infusion; Table 2), it still cannot clarify why fitted $A$ for this urea infusion rate explains only $73 \%$ instead of $100 \%$ of injected ${ }^{15} \mathrm{~N}$. A fifth possibility is that injected labeled urea is rapidly distributed over the mammary gland urea space volume and that this mammary gland urea space volume is larger than the milk volume. We suggest this fifth possibility is the most likely cause of a fitted initial recovery of $70.1 \%$ on average.

\section{Urea Diffusion Within the Mammary Gland}

The distribution pattern of $\left[{ }^{15} \mathrm{~N}^{15} \mathrm{~N}\right]$ urea within the mammary gland in time as shown in Figure 2 is similar to that established in a previous study of Spek et al. (2012a) showing a curve that can be described by a third-order polynomial. Within $20 \mathrm{~min}$ after injection of $\left[{ }^{15} \mathrm{~N}^{15} \mathrm{~N}\right]$ urea in the cisterns, the ${ }^{15} \mathrm{~N}$-urea was homogenously distributed throughout the milk present in the milk fraction 0.2 to 0.9 (Figure 2). This rapid distribution of $\left[{ }^{15} \mathrm{~N}^{15} \mathrm{~N}\right]$ urea injected in the cisterns toward alveoli milk seems in support of the assumption of a single compartment for milk in the mammary gland. However, the finding of slightly higher ${ }^{15} \mathrm{~N}$-urea enrichment values between milk fraction 0.5 and 0.8 (milk likely originating from the ducts and alveoli) compared with the fraction between 0.4 and 0.5 is actually an indi- cation of the existence of multiple milk compartments. Explanations for the observed enrichment pattern in various parts of milk (from high to low during milking) include (1) the last fraction of milk being also furthest away from the site of injection of the pulse doses of $\left[{ }^{15} \mathrm{~N}^{15} \mathrm{~N}\right]$ urea, (2) milk in alveoli having a larger surface area of exchange with plasma per volume of milk compared with duct and cistern, resulting in more labeled urea being transferred to blood plasma and dilution of milk urea with unlabeled urea from blood plasma, and (3) part of the arginine entering the alveoli cells from the blood being converted into ornithine and urea, resulting in a dilution of the concentration of labeled urea in alveoli milk (Mepham, 1982). Little work has been done, however, on quantifying the extent of diffusion within the mammary gland. Linzell and Peaker (1971) reported that, from the quantity of labeled lactose injected in the teats of goats, after 10 and 20 min, 7 and $14 \%$ reached the residual (alveoli) milk, respectively.

\section{Modeling Urea Fluxes Between Plasma and Milk}

Diurnal variation in blood plasma and milk urea concentrations occurs (Spek et al. 2013), and if milk urea is to be used as an indicator of urinary $\mathrm{N}$ excretion, improved quantitative understanding of such variation may help to improve relationships between MUN and $\mathrm{N}$ excretion. Rate of transfer of urea between blood and milk partly determines the relationship between blood plasma and milk urea. This transfer may be determined by factors that affect movement of urea across the membranes of capillaries and udder cells, and likely involves factors such as surface area of exchange between plasma and milk, blood flow, and the speed at which urea molecules move across membranes between plasma and milk.

The average of estimated $K_{\text {urea }}$ values $(\mathrm{n}=12)$ is $0.547 \pm 0.1212$ per hour. Assuming this fractional rate applies to the dynamics of urea transfer from blood plasma to milk, and vice versa, it can be calculated what time period is required for urea- $\mathrm{N}$ concentrations in plasma and milk in dairy cattle to reach equilibrium after PUN is increased relative to MUN due to protein intake. In these calculations, a volume of milk in the mammary gland and a body distribution volume of urea of 15 and $325 \mathrm{~L}$ ( $50 \%$ of BW), respectively, an initial MUN of $10.5 \mathrm{mg}$ of N/dL, a constant PUN of $14.0 \mathrm{mg}$ of $\mathrm{N} / \mathrm{dL}$, and a $K_{\text {urea }}$ of 0.547 per hour were assumed. It was furthermore assumed that when PUN and MUN are in equilibrium, the absolute flux of urea from milk to plasma is equal to the urea flux of plasma to milk. Because of the larger pool of urea in the plasma, the fractional disappearance rate of urea from plasma to milk was calculated as $15 \mathrm{~L}$ (urea distribution volume 
of milk) $/ 325 \mathrm{~L}$ (body urea distribution volume) $\times 0.547$ equaling 0.0252 per hour. The following equations were used to calculate the time period that is required for urea- $\mathrm{N}$ concentrations in plasma and milk to reach equilibrium after a $3.5 \mathrm{mg}$ of $\mathrm{N} / \mathrm{dL}$ increase in PUN relative to MUN observed in the study of Gustafsson and Palmquist (1993) for one cow:

urea flow from milk to plasma (g of urea-N/h) = volume of milk $(\mathrm{L}) \times$ urea- $\mathrm{N}$ concentration of milk $(\mathrm{g}$ of $\mathrm{N} / \mathrm{L}) \times$ fractional rate of urea-N disappearance to blood (per hour),

urea flow from plasma to milk (g of urea-N/h) $=$ volume of plasma $(\mathrm{L}) \times$ urea-N concentration of plasma $(\mathrm{g}$ of $\mathrm{N} / \mathrm{L}) \times$ fractional rate of urea-N disappearance to milk (per hour), and

urea-N pool in milk (g of urea-N) at time $t+\Delta t=$ initial urea-N pool in milk (g of urea-N) at time $t$ - urea flow from milk to blood at time $t$

(g of urea-N/h) + urea flow from plasma to milk at time $t$ (g of urea-N/h).

Using time steps $\Delta t$ of $0.001 \mathrm{~h}$, calculations showed that $89 \%$ of the initial difference between PUN and MUN disappeared after $4 \mathrm{~h}$. This is somewhat longer than the 1 to $2 \mathrm{~h}$ required to reach equilibrium mentioned by Gustafsson and Palmquist (1993). However, the time course of the urea concentration in blood plasma and milk they measured after a meal can be used to evaluate the urea dynamics established in the present study. The graphically reported PUN and MUN values in the study of Gustafsson and Palmquist for one cow were used for further calculations, with the results shown in Figure 3. Calculations were performed adopting a recorded volume of afternoon milk of $12.9 \mathrm{~L}$, and observed PUN values after feeding were used as inputs. A urea distribution volume in the body of $328 \mathrm{~L}$ (50\% of reported BW) was assumed, and Equations 1, 2, and 3 were applied to perform the calculations iteratively with time steps of $0.001 \mathrm{~h}$ for $12 \mathrm{~h}$. Values of PUN in time were estimated by linear interpolation of observed PUN values. The model was run using 3 different $K_{\text {urea }}$ values of $0.429,0.547$, and 0.641 per hour $\left(K_{\text {urea }}\right.$ at the lowest urea infusion rate, the average of estimated values, and at the highest urea infusion rate, respectively). Results show that the predicted MUN matched closely with observed development in PUN and MUN after feeding (Figure 3), which suggests that $K_{\text {urea }}$ values established in the present study are realistic for the testing conditions of Gustafsson and Palmquist (1993) as well. Results indicate that the higher $K_{\text {urea }}$ value of 0.641 per hour is best able to explain the increase in MUN following an increase in PUN, whereas the lowest $K_{\text {urea }}$ value of 0.429 per hour is best able to explain the decrease in MUN following a decrease in PUN. The current approach supports the concept that diurnal variation in MUN needs to be calculated from diurnal variation in PUN and that fractional transfer rates of urea from plasma to milk and vice versa may not be constant but higher with higher PUN and MUN concentrations. Such calculations are required to be able to interpret the effect of feed intake patterns on diurnal variation in PUN, and subsequently on MUN. A better understanding of the effect of diurnal variation in PUN on MUN increases the utility for MUN as an indicator for $\mathrm{N}$ excretion in urine.

\section{CONCLUSIONS}

The fractional urea disappearance rate from milk to blood varied between $0.429(0 \mathrm{~g} / \mathrm{h}$ intravenous urea

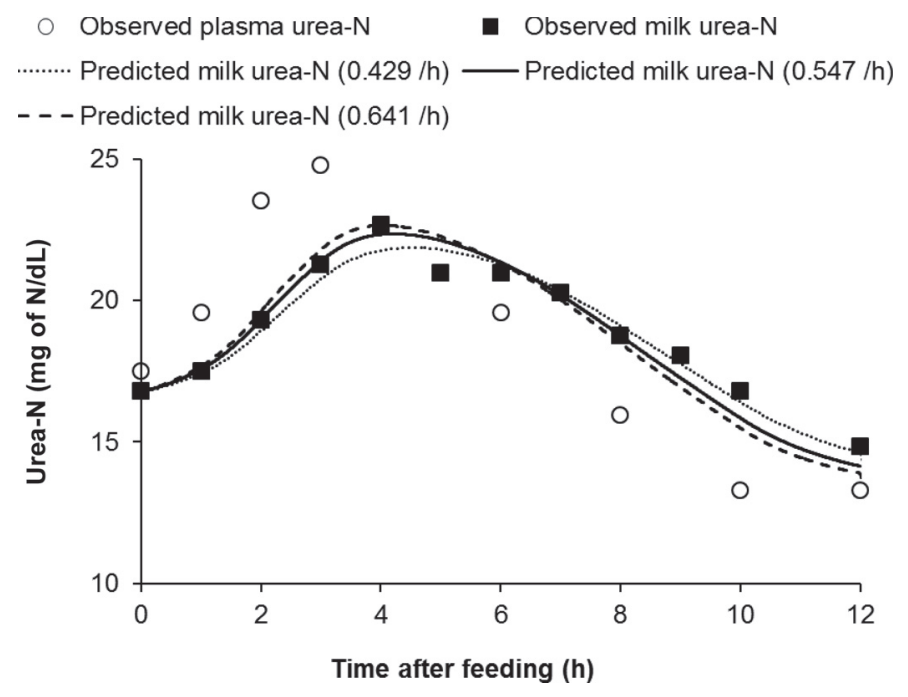

Figure 3. Development of urea-N concentration in blood plasma (open circles) and milk (closed squares) in time (h) after feeding as reported by Gustafsson and Palmquist (1993). Predicted milk urea-N concentrations (lines) were predicted using the calculations and assumptions described in the Discussion section Modeling Urea Fluxes Between Plasma and Milk and a fractional disappearance rate of urea from milk to blood plasma ( $K_{\text {urea }}$, per hour) of 0.429 per hour (lowest estimate in combination with a fractional urea flux from plasma to milk of 0.0169 per hour; dotted line), 0.547 per hour (mean of estimates in combination with a fractional urea flux from plasma to milk of 0.0215 per hour; solid line), and 0.641 per hour (highest estimate in combination with a fractional urea flux from plasma to milk of 0.0252 per hour; dashed line). 
infusion) and 0.641 per hour $(15 \mathrm{~g} / \mathrm{h}$ intravenous urea infusion). The higher value seems more appropriate because of the high milk urea content and smaller effect of nonurea- $\mathrm{N}$ compounds in milk on recovery of infused ${ }^{15} \mathrm{~N}$ urea. The results suggest that urea disappearance from milk in the mammary gland is fast and substantial, as well as intramammary urea transfer between milk in the cisterns, ducts, and alveoli. However, the inference range of this study is limited given the lack of full recovery of dosed ${ }^{15} \mathrm{~N}$ urea at time of injection. Information on the fractional disappearance rate of urea from the mammary gland may be useful with the aim to quantify the effect of diurnal variation in PUN on variation in MUN. This information aids in understanding how to make use of MUN as an indicator for $\mathrm{N}$ excretion in urine with different feeding regimens and production conditions.

\section{ACKNOWLEDGMENTS}

This study was funded by the Dutch Dairy Board (PZ, Zoetermeer, the Netherlands), the Dutch Product Board Animal Feed (PDV, Zoetermeer, the Netherlands), the Dutch Ministry of Economic Affairs (EZ, The Hague, the Netherlands), and Wageningen UR Livestock Research.

\section{REFERENCES}

Abrahamse, P. A., J. Dijkstra, B. Vlaeminck, and S. Tamminga. 2008 Frequent allocation of rotationally grazed dairy cows changes grazing behavior and improves productivity. J. Dairy Sci. 91:20332045.

Agle, M., A. N. Hristov, S. Zaman, C. Schneider, P. Ndegwa, and V. K. Vaddella. 2010. The effects of ruminally degraded protein on rumen fermentation and ammonia losses from manure in dairy cows. J. Dairy Sci. 93:1625-1637.

Boucher, S. E., R. S. Ordway, N. L. Whitehouse, F. P. Lundy, P. J. Kononoff, and C. G. Schwab. 2007. Effect of incremental urea supplementation of a conventional corn silage-based diet on ruminal ammonia concentration and synthesis of microbial protein. J. Dairy Sci. 90:5619-5633.

Burgos, S. A., J. G. Fadel, and E. J. DePeters. 2007. Prediction of ammonia emission from dairy cattle manure based on milk urea nitrogen: Relation of milk urea nitrogen to urine urea nitrogen excretion. J. Dairy Sci. 90:5499-5508.

Ciszuk, P., and T. Gebregziabher. 1994. Milk urea as an estimate of urine nitrogen of dairy cows and goats. Acta Agric. Scand. Anim. Sci. 44:87-95.
Cui, X., Y. Hou, S. Yang, Y. Xie, S. Zhang, Y. Zhang, Q. Zhang, X. Lu, G. E. Liu, and D. Sun. 2014. Transcriptional profiling of mammary gland in Holstein cows with extremely different milk protein and fat percentage using RNA sequencing. BMC Genomics. 15:226.

Cummins, B., P. O'Kiely, M. G. Keane, and D. A. Kenny. 2009. Feed intake pattern, behaviour, rumen characteristics and blood metabolites of finishing beef steers offered total mixed rations constituted at feeding or ensiling. Ir. J. Agric. Food Res. 48:57-73.

Gustafsson, A. H., and D. L. Palmquist. 1993. Diurnal variation of rumen ammonia, serum urea, and milk urea in dairy cows at high and low yields. J. Dairy Sci. 76:475-484.

Hommez, J., L. A. Devriese, M. Vaneechoutte, P. Riegel, P. Butaye, and F. Haesebrouck. 1999. Identification of nonlipophilic corynebacteria isolated from dairy cows with mastitis. J. Clin. Microbiol. $37: 954-957$.

ISO. 2004. Milk. Determination of urea content-Enzymatic method using difference in $\mathrm{pH}$ (Reference method). ISO 14637:2004. Int. Org. Stand., Geneva, Switzerland.

Knodt, C. B., and W. E. Petersen. 1944. The effect of complete evacuation of the mammary gland by pitocin upon milk and fat production. J. Dairy Sci. 27:449-457.

Linzell, J. L., and M. Peaker. 1971. The permeability of mammary ducts. J. Physiol. 216:701-716.

Mepham, T. B. 1982. Amino acid utilization by lactating mammary gland. J. Dairy Sci. 65:287-298.

Nousiainen, J., K. J. Shingfield, and P. Huhtanen. 2004. Evaluation of milk urea nitrogen as a diagnostic of protein feeding. J. Dairy Sci. 87:386-398.

Piccione, G., A. Foà, C. Bertolucci, and G. Caola. 2006. Daily rhythm of salivary and serum urea concentration in sheep. J. Circadian Rhythms 4:16.

Røjen, B. A., P. K. Theil, and N. B. Kristensen. 2011. Effects of nitrogen supply on inter-organ fluxes of urea-N and renal urea-N kinetics in lactating Holstein cows. J. Dairy Sci. 94:2532-2544.

Spek, J. W., A. Bannink, G. Gort, W. H. Hendriks, and J. Dijkstra. 2012b. Effect of sodium chloride intake on urine volume, urinary urea excretion, and milk urea concentration in lactating dairy cattle. J. Dairy Sci. 95:7288-7298.

Spek, J. W., J. Dijkstra, J. J. G. C. van den Borne, and A. Bannink. 2012a. Short communication: Assessing urea transport from milk to blood in dairy cows. J. Dairy Sci. 95:6536-6541.

Spek, J. W., J. Dijkstra, G. Van Duinkerken, and A. Bannink. 2013 A review of factors influencing milk urea concentration and its relationship with urinary urea excretion in lactating dairy cattle. J. Agric. Sci. 151:407-423.

Van Duinkerken, G., M. C. Blok, A. Bannink, J. W. Cone, J. Dijkstra, A. M. Van Vuuren, and S. Tamminga. 2011a. Update of the Dutch protein evaluation system for ruminants: The DVE/OEB2010 system. J. Agric. Sci. 149:351-367.

Van Duinkerken, G., M. C. J. Smits, G. André, L. B. J. Šebek, and J. Dijkstra. 2011b. Milk urea concentration as an indicator of ammonia emission from dairy cow barn under restricted grazing. J. Dairy Sci. 94:321-335.

Van Es, A. J. H. 1975. Feed evaluation for dairy cows. Livest. Prod. Sci. 2:95-107. 